\title{
ANATOMI DAN GAMBARAN KLINIS VARIKOKEL
}

\author{
${ }^{1} \mathrm{Al}$ Muqsith \\ ${ }^{1}$ Bagian Anatomi Fakultas Kedokteran Universitas Malikussaleh \\ Lhokseumawe-Aceh 24352, Indonesia \\ *Corresponding Author: almuqsith@unimal.ac.id
}

\begin{abstract}
Abstrak
Varikokel merupakan dilatasi abnormal pleksus pampiniformis yang terjadi pada $15 \%$ pria. Varikokel lebih sering terdeteksi pada populasi pria infertil dibandingkan dengan pria fertil, terdiagnosis pada $20-40 \%$ pasien infertil. Umumnya dijumpai pada anak remaja dan pria dewasa. Adanya varikokel dikaitkan dengan kegagalan dari fungsi testis. Artikel ini ditulis untuk menjelaskan gambaran klinis varikokel. Dengan mengetahui gambaran klinis dari varikokel diharapkan para klinisi dapat lebih mudah dan cepat mendiagnosis serta memberikan penatalaksanaan yang tepat sehingga memberikan prognosis yang baik untuk penderita. Gambaran klinis yang sering dijumpai pada pasien varikokel berupa benjolan di atas testis dan nyeri pada testis. Varikokel dapat didiagnosis dengan melakukan beberapa pemeriksaan seperti pemeriksaan fisik dan pemeriksaan penunjang. Pemeriksaan Ultrasonografi merupakan pilihan pertama, non invasif dan akurat dalam mendeteksi varikokel.
\end{abstract}

Kata kunci: Varikokel; pleksus pampiniformis; ultrasonografi

\begin{abstract}
Varicocele is an abnormal dilatation of the pampiniform plexus occuring in $15 \%$ of men. Varicocele is more frequently detected in infertile male populations than in fertile men, 20-40\% diagnosed of varicocele was obtained from infertile men. Its commonly found in children and adult men. The presence of a varicocele is associated with failure of the testicular function. This article was written to explain the clinical features of varicocele. By knowing the clinical features of the varicocele it is hoped that clinicians can be more easily and promptly to diagnose and provide the right management thus providing a good prognosis for the patient. Clinical features that are often seen in patients with varicocele are lumps and pain above the testes. Varicocele can be diagnosed by performing several checks such as physical examination and investigation. Ultrasound examination is the gold strandard, non invasive and accurate in detecting varicocele.
\end{abstract}

Keywords: Varicocele; plexus pampiniformis; ultrasonography

\section{Pendahuluan}

Varikokel adalah dilatasi abnormal dari vena pada pleksus pampiniformis akibat dari gangguan aliran balik vena spermatika interna. Kelainan ini terdapat pada $15 \%$ pria. Varikokel juga merupakan salah satu penyebab infertilitas pada pria. Varikokel lebih sering terdeteksi pada populasi pria infertil dibandingkan dengan pria fertil. Adanya varikokel telah dikaitkan dengan kegagalan fungsi testis, sering menyebabkan kelainan pada parameter semen. Varikokel umum dijumpai pada anak remaja dan pria dewasa, terdiagnosis pada 20$40 \%$ pasien infertil ${ }^{1,2}$.

Varikokel digambarkan sebagai "kantung cacing" oleh Dubin dan Amelar pada tahun 1970 dan beberapa peneliti menyebutkan varikokel adalah abnormalitas dilatasi vena dari pleksus pampiniformis yang disebabkan oleh berbagai etiologi. WHO melaporkan bahwa 
varikokel terdapat pada $25 \%$ pasien dengan parameter sperma abnormal dan $12 \%$ pada pasien dengan parameter sperma normal. Kondisi varikokel ini biasa ditemukan pada sisi kiri testis. 90\% kasus terdapat pada sisi kiri testis dan hanya 2\% kasus terdapat pada sisi kanan testis. Pemeriksaan Utrasonografi merupakan pilihan pertama, non invasif, relatif mudah dan akurat dalam mendeteksi varikokel. Pemeriksaan ultrasonografi Color Doppler (CDUS) telah menjadi modalitas yang telah diterima secara luas dan sering digunakan untuk mengevaluasi varikokel $^{3,4}$.

\section{Diskusi}

Varikokel terdeteksi lebih sering pada populasi pria infertil dibanding pada pria fertil. Sebagian besar varikokel terdeteksi setelah pubertas dan prevalensi pada pria dewasa sekitar 11-15\%. Pada 80-90\% kasus, varikokel hanya terdapat pada sebelah kiri ${ }^{2,5}$.

Hingga sekarang masih belum diketahui secara pasti penyebab dari verikokel tetapi dari penelitian membuktikan bahwa varikokel sebelah kiri lebih sering dijumpai daripada sebelah kanan. Hal ini dikarenakan vena spermatika interna kiri bermuara pada vena renalis kiri dengan arah tegak lurus, sedangkan yang kanan bermuara pada vena kava dengan arah miring. Di samping itu vena spermatika interna kiri lebih panjang daripada yang kanan. Jika terdapat varikokel di sebelah kanan atau varikokel bilateral patut dicurigai adanya kelainan pada rongga retroperitoneal, muara vena spermatika kanan pada vena renalis atau adanya situs inversus $^{2}$.

Varikokel dapat menimbulkan gangguan proses spermatogenesis melalui beberapa cara, antara lain: terjadi stagnasi darah balik pada sirkulasi testis sehingga testis mengalami hipoksia karena kekurangan oksigen, refluks hasil metabolit ginjal dan adrenal melalui vena spermatika interna ke testis, peningkatan suhu testis, serta adanya anastomosis antara pleksus pampiniformis kiri dan kanan, memungkinkan zat-zat hasil metabolit tadi dapat dialirkan dari testis kiri ke testis kanan sehingga menyebabkan gangguan spermatogenesis testis kanan dan akhirnya terjadi infertilitasi ${ }^{2}$.

Beberapa pasien dengan varikokel dapat mengalami nyeri skrotal dan pembengkakan, namun yang lebih penting, suatu varikokel dipertimbangkan menjadi suatu penyebab potensial infertilitas pria ${ }^{2}$. Varikokel dapat menyebabkan keluhan testis terasa membengkak, hal ini terjadi akibat tekanan yang meninggi di dalam pleksus pampiniformis ${ }^{6}$.

Diagnosis ditegakkan dengan melakukan pemeriksaan fisik. Pemeriksaan dilakukan dalam posisi berdiri dengan memperhatikan keadaan skrotum kemudian dilakukan palpasi. Pasien juga diminta untuk melakukan maneuver valsava atau mengedan. Jika terdapat varikokel, dari 
hasil inspeksi dan palpasi terdapat bentukan seperti kumpulan cacing-cacing di dalam kantung yang berada di sebelah kranial testis. Secara klinis varikokel dibedakan dalam 3 tingkatan: (1) derajat kecil, varikokel yang dapat dipalpasi setelah pasien melakukan maneuver valsava; (2) derajat sedang, varikokel yang dapat dipalpasi tanpa melkukan maneuver valsava; (3) derajat besar: varikokel yang sudah dapat dilihat bentuknya tanpa melakukan maneuver valsava ${ }^{2,7}$.

Pemeriksaan radiologi juga dapat membantu dalam penengakan diagnosis. USG tidak diindikasikan untuk diagnosis dari varikokel tetapi dapat membantu jika diagnosis belum dapat dipastikan, seperti pada pasien dengan obesitas morbid, pembedahan skrotum sebelumnya atau terdapat hidrokel sebelumnya. Spermatic cord dan epididimis dapat dievaluasi dengan USG konvensional. Saat ini USG Doppler sudah menjadi alat standar diagnostik. Disarankan agar setidaknya pasien melakukan satu pemeriksaan pencitraan dan pemeriksaan fisik. Dengan menggunakan USG Doppler aliran darah ke tesis dapat dinilai. Tingkatan varikokel menurut refluk vena dengan menggunakan Doppler: (Grade 1), reflaks vena tidak spontan; (Grade 2), reflaks vena spontan dan jarang; (Grade 3), reflaks vena spontan dan terus menerus ${ }^{3}$.

Terdapat dua pendekatan untuk perbaikan dari varikokel, yaitu operasi dan perkutaneus emboli. Bedah perbaikan varikokel dilakukan dengan berbagai metode bedah terbuka termasuk retroperitoneal, inguinal dan subinguinal atau dengan laparoskopi ${ }^{2,7,8,9,}$.

1. Pembedahan

Pada pembedahan terdapat tiga tehnik yang umum dilakukan. Ketiga tehnik tersebut yaitu ligasi sub-inguinal, ligasi inguinal dan ligasi retroperitoneal. Ligasi varikokel laparoskopi belum membuktikan bahwa tehnik tersebut merupakan yang paling unggul terhadap operasi pembedahan dan hal ini mungkin berhubungan dengan komplikasi serius yang ditimbulkannya.

2. Embolisasi perkutaneus

Penatalaksanaan emboli perkutaneus lebih kurang menyakitkan dibandingkan tatalaksana pembedahan, tetapi diperlukan dokter yang pengalaman dalam intervensi radiologi.

Tidak semua pasien membaik setelah dilakukan varikokolektomi. Pasien dengan riwayat penyakit kurang dari 2 tahun dan yang memiliki grade varikokel yang tinggi cenderung meningkat setelah varikokolektomi. Pasien dengan jumlah total motil sperma kurang dari 5 juta yang memiliki kelainan genetik, ukuran testis kecil atau sindrom metabolik memiliki prognosis pengobatan yang buruk ${ }^{3}$. Kira-kira $2 / 3$ pasien yang telah melakukan operasi akan mengalami perbaikan motilitas spermatozoanya ${ }^{10}$. 


\section{Kesimpulan}

Varikokel merupakan dilatasi abnormal pleksus pampiniformis yang terjadi pada $15 \%$ pria. Varikokel lebih sering terdeteksi pada populasi pria infertil dibandingkan dengan pria fertil, terdiagnosis pada $20-40 \%$ pasien infertil. Umumnya dijumpai pada anak remaja dan pria dewasa. Adanya varikokel dikaitkan dengan kegagalan dari fungsi testis. Gambaran klinis yang sering dijumpai pada pasien varikokel berupa benjolan di atas testis dan nyeri pada testis. Varikokel dapat didiagnosis dengan melakukan beberapa pemeriksaan seperti pemeriksaan fisik dan pemeriksaan penunjang. Pemeriksaan fisik dilakukan dalam posisi berdiri dengan memperhatikan keadaan skrotum kemudian dilakukan palpasi. Pemeriksaan Ultrasonografi merupakan pilihan pertama, non invasif dan akurat dalam mendeteksi varikokel.

\section{DAFTAR PUSTAKA}

1. Purnomo, BB, Dasar-dasar Urologi, Sagung Seto, Jakarta, 2011.

2. Sener, NC, Nalbant, I, Ozturk, U, Varicocele: A Review, EMJ Repro Health ;1[1]:54-58, 2015 .

3. Sjamsuhidajat R, Jong, WD, Buku Ajar Ilmu Bedah, Edisi ke-2, Penerbit Buku Kedokteran-EGC, Jakarta, 2005.

4. Sakti, H, Vasoligasi Tinggi Vena Spermatika Interna Pada Pasien Varikokel; Pengaruhnya Terhadap Volume Testis dan Kualitas Semen, 2003, Diunduh: 28 Semptember 2017 dari $<$ http://www.urologi.or.id/pdf $>$

5. Hafid, Abdu Syukur, Saluran Kemih dan Alat Kelamin Lelaki, Buku Ajar Ilmu Bedah, Edisi ke-2, EGC, Jakarta, 2004.

6. Anwar, S. Pedoman Diagnosis dan Terapi, SMF Urologi Laboraturium Ilmu Bedah, Malang, 2010.

7. Sharlip, I., Jarrow, J, Report on Varicocele and Infertility, American Urological Association, San Francisco, CA, 2001.

8. Willams, HD, Karpman, E, Lipshlutz, LI, Varicocele, Department of Urology, Texas, USA, 2005.

9. Hanno, P, Male Fertility and Clinical Manual of Urology In Third Edition, McGraw-Hill, Boston, 2001.

10. Wiknjosastro, H, Infertilitas Ilmu Kandungan, PT Bina Pustaka Sarwono Prawirohardjo, Jakarta, 2008. 